\title{
Breves reflexões sobre os fundamentos da pena
}

\author{
Breves reflexiones sobre los fundamentos de la pena
}

Stephanie Carolyn Perez*

\section{REFERÊNCIA}

PEREZ, Stephanie Carolyn. Breves reflexões sobre os fundamentos da pena. Revista da Faculdade de Direito da UFRGS, Porto Alegre, n. 42, p. 194-223, abr. 2020. DOI: <https://doi.org/10.22456/0104-6594.94873>.

\section{RESUMO}

Este artigo acadêmico tem como objetivo analisar e propor reflexões sobre os fundamentos da pena, por meio de uma análise histórica de como ocorreu o fenômeno punitivo durante os principais períodos da história da humanidade até chegar aos dias atuais. O que se pretende não é apenas possibilitar ao leitor o conhecimento das mais importantes correntes punitivas, mas também criar novos enfoques e debates construtivos acerca do tema.

\section{PALAVRAS-CHAVE}

Fundamentos da pena. Sistema punitivo. Teoria dos fins da pena.

\section{RESUMEN}

Este artículo académico tiene como objetivo analizar y proponer reflexiones sobre los fundamentos de la pena, por medio de un análisis histórico de como se dio el fenómeno punitivo durante los principales períodos de la historia de la humanidad hasta llegar a los días actuales. Lo que se desea no es solo posibilitar al lector el conocimiento de las más importantes corrientes punitivas, sino también crear nuevos enfoques y debates constructivos sobre el tema.

\section{PALABRAS CLAVE}

Fundamentos de la pena. Sistema punitivo. Teoría de los fines de la pena.

\section{ABSTRACT}

This article aims to analyze and propose reflections on the foundations of punishment through a historical analysis of how the punitive phenomenon occurred during the main periods of human history up to the present time. The aim is not only to enable the reader to learn about the most important punitive traditions, but also to create new approaches and constructive debates on the subject.

\section{KEYWORDS}

Foundations of the punishment. Punitive system. Purposes of the punishment.

\section{SUMÁRIO}

1. Introdução. 2. Teorias dos fins da pena. 2.1. Teorias absolutas ou de justiça - pena retributiva e expiatória. 2.2. Teorias relativas - prevenção geral - prevenção especial - concepção utilitária da pena. 2.3. Teorias unitárias, ecléticas ou unificadas. 2.4. Teorias negativas ou agnósticas. 3. Conclusão. Referências. Dados da publicação.

\footnotetext{
* Doutoranda em Direito Penal pela Universidad de Buenos Aires. Mestre e Bacharel em Direito pela Pontifícia Universidade Católica de São Paulo. Advogada Criminalista.
} 


\title{
1 INTRODUÇÃO
}

Sabemos que os atuais sistemas penais estão alicerçados em postulados progressistas e humanitários acerca do fenômeno punitivo. É dizer: a despeito da existência da pena e da necessidade de o Estado punir o agente criminoso, a pena deve sempre ser imposta com base nos direitos e garantias fundamentais do ser humano, evitando assim a existência - e consequentemente a aplicação - de penas cruéis, desumanas ou que de alguma forma não respeitem o postulado da dignidade da pessoa humana. Entretanto, nem sempre foi assim. Nos povos primitivos a pena estava sempre atrelada ao sentimento de vingança daquele que foi vítima de um delito. Naquele período eram comuns as práticas de vingança privada como forma de punição, que traziam consigo guerras infindáveis entre grupos familiares, enfraquecendo assim o grupo social como um todo. Com o passar do tempo, os grupos sociais e as pequenas comunidades passaram por notória evolução e progresso. A partir desse momento a sociedade passou a sentir a necessidade de criação de um poder central que seria responsável pela aplicação das penas aos agentes infratores da norma jurídica. Surge assim a figura do Estado, que assumiu o monopólio do jus puniendi. As práticas de vingança privada foram então substituídas pelas penas públicas. Para René Ariel Dotti:

\begin{abstract}
A ideia da pena como instituição de garantia social foi obtendo disciplina através da evolução política da comunidade (grupo, cidade, Estado) e o reconhecimento da autoridade de um chefe a quem era deferido o poder de castigar em nome dos súditos. É a pena pública que, embora impregnada pela vingança, penetra nos costumes sociais e procura alcançar a proporcionalidade através das formas do talião e da composição. A expulsão da comunidade é substituída pela morte, mutilação, banimento temporário ou perdimento de bens. ${ }^{1}$
\end{abstract}

O direito de punir estava diretamente relacionado com o poder. Somente podia punir aquele tinha o poder, ou seja, o Estado. Punir era impor ao acusado a marca visível do poder.

Já na Antiguidade, a aplicação de uma pena era justificada com base em fundamentos religiosos, com o objetivo de satisfazer a divindade que havia sido ofendida pela prática do delito. Nesse período era comum a prática dos sacrifícios, que buscavam não apenas afastar a raiva e a ira dos deuses, mas também trazer a purificação da sociedade, impedindo a disseminação da vingança entre os seus membros. Assim era na sociedade judaica, egípcia e até mesmo entre os hindus. É, contudo, com o início da Idade Média que surgem as manifestações mais importantes acerca da aplicação da pena no mundo ocidental. Assim

1 DOTTI, René Ariel. Bases e alternativas para o sistema de penas. 2. ed. São Paulo: Revista dos Tribunais, 1998. p. 31. 
como ocorria na Antiguidade, acreditava-se que ao praticar um crime o sujeito estava ofendendo a Deus e por esta razão deveria ser castigado para que pudesse salvar sua alma e ter uma vida eterna. Neste período a Igreja passou a ter forte influência nas questões e decisões do Estado, tanto assim que por muito tempo o Direito Canônico foi o único compilado de normas existente. Ressalte-se que para a sociedade medieval tudo, inclusive o poder, vinha de Deus. Dizia-se, então, que o direito de punir vinha dos céus e cabia à Igreja o direito de castigar o criminoso, salvando assim a sua alma. A Igreja contribuiu com o enfraquecimento não apenas da vingança privada, mas também dos ordálios ou juízos de Deus, ambos trazidos pelos povos germânicos, que consistiam em práticas marcadas pela crueldade e pelas superstições aplicadas aos criminosos que eram obrigados, por exemplo, a caminhar sobre o fogo para provar sua inocência. As práticas punitivas desse período são bem retratadas por Santo Agostinho e por São Tomás de Aquino, que em suas obras tratavam da justiça divina.

Seguindo nesta breve introdução acerca da evolução da aplicação das penas ao longo da história da humanidade chegamos ao período da Idade Moderna, que precedeu o período do Absolutismo e foi marcado pelas ideias e princípios avançados de alguns pensadores em contraposição às práticas medievais no tocante à punição. Entre os autores que retrataram esse período podemos citar Maquiavel com sua obra "O Príncipe" e Thomas Hobbes com sua obra "Leviatã". Para Maquiavel os fins justificavam os meios, pouco importando se os meios viessem a colocar em risco os direitos e garantias de cada indivíduo membro da sociedade. A propósito, Maquiavel defendia o poder de intimidação do castigo aplicado pelo príncipe, nos seguintes termos:

[...] não se preocupar com a fama de cruel se desejar manter seus súditos unidos e obedientes. Dando os pouquíssimos exemplos necessários, será mais piedoso do que aqueles que, por excessiva piedade, deixam evoluir as desordens, das quais resultam assassínios e rapinas; porque estes costumam prejudicar uma coletividade inteira, enquanto as execuções ordenadas pelo príncipe ofendem apenas um particular. ${ }^{2}$

Da análise do pensamento de Maquiavel acima transcrito é possível verificar que o filósofo justificava a aplicação de castigos pelo príncipe em nome da segurança de toda a sociedade. Essa mesma intimidação punitiva viria a ser, pouco mais tarde, um dos maiores pilares de sustentação do Absolutismo.

Também podemos citar as ideias defendidas por Thomas Hobbes, conhecido por sua teoria contratual, o chamado pacto social para conservação e pacificação da sociedade. Para o 
filósofo, os homens viviam em constante estado de guerra de uns contra outros ("o homem é o lobo do homem") e somente a partir da eleição de um único homem (o soberano) para exercer o poder de forma absoluta é que poderia existir paz social. Assim, para Thomas Hobbes as vontades humanas deveriam estar subordinadas à uma só vontade: a vontade do soberano. A respeito da aplicação das penas, o filósofo defendia que o castigo aplicado ao criminoso além de retribuir o mal praticado deveria servir como exemplo para os demais membros da sociedade, para que estes não cometessem delitos: "de todas as paixões, a que menos faz os homens tender a violar as leis é o medo". ${ }^{3}$

Prosseguindo com esta breve análise, entre os séculos XV e XVIII a sociedade europeia passou por diversas transformações em sua estrutura, especialmente com relação à formação dos Estados Nacionais e à substituição dos feudos pelos regimes de monarquia absoluta, cujo período mais significativo remonta ao reinado de Luís XIV. Durante o período do Absolutismo a lei emanava da vontade soberana do rei, que não reconhecia a existência de nenhum outro poder e agia sempre de forma ilimitada, sem qualquer exercício de controle de suas ações. Não por acaso, Luís XIV dizia: “L'Etat c'est moi”. Acreditava-se que o soberano era a representação do próprio Deus na sociedade, razão pela qual se dizia que o poder do soberano era um poder divino, vindo dos céus.

E foi justamente nesse período em que ocorreram as piores manifestações do desequilíbrio na aplicação da pena. Isso porque o período do Absolutismo foi marcado por uma execução da pena que sempre se dava de forma violenta, cruel e desumana. Neste período eram muito comuns os suplícios, castigos corporais aplicados aos condenados pelo cometimento de infrações penais. Os suplícios eram praticados em praça pública, para que toda a população pudesse assistir com seus próprios olhos o que o soberano era capaz de fazer com aqueles que cometessem crimes, demonstrando o caráter essencialmente retributivo da pena.

Neste contexto não há como deixar de mencionar a obra "Vigiar e Punir: nascimento da prisão", do filósofo francês Michel Foucault, que muito bem retratou as questões sociais que motivaram as grandes mudanças que ocorreram no sistema penal durante a era moderna.

Michel Foucault narrou em sua obra que os suplícios, conhecidos como castigos corporais aplicados aos condenados, eram uma espécie de ritual, que ao mesmo tempo puniam aqueles que havia praticado um crime (função retributiva da pena) e ainda serviam de

3 HOBBES, Thomas. Leviatã ou matéria, forma e poder de uma República eclesiástica e civil. São Paulo: Martins Fontes, 2003. p. 253. 
exemplo, pois por meio dos suplícios o soberano mostrava para a sociedade o que acontecia com quem cometia algum tipo de crime (função preventiva da pena).

Michel Foucault disse que o suplício era marcante em relação à vítima, pois deveria deixar no corpo do condenado marcas que não deveriam ser apagadas sequer pela memória dos homens. Com relação à justiça, o suplício era ostentoso, demonstrando a todos a glória da justiça. Era por meio do suplício que a justiça manifestava sua força, ainda que na época clássica não houvesse o devido processo legal e o condenado não fosse julgado de forma democrática, tal como ocorre nos dias de hoje.

Para Diego Zysman Quirós:

\begin{abstract}
Foucault ha explicado persuasivamente esta racionalidad del castigo, afirmando que las ceremonias públicas tenían lugar en el marco del ejercicio de un poder soberano - y por ende jerárquico y necesariamente arbitrario - para el cual eran imprescindibles "toda la serie de los grandes rituales del poder eclipsado y restaurado..." en los que se desplegaba la fuerza invencible del monarca, como en la coronación o la entrada triunfal del rey en la ciudad conquistada. ${ }^{4}$

$[\ldots]$

Mientras la ceremonia, la publicidad de la ejecución y sus consecuencias hacían visible el poder de castigar, el sufrimiento físico acompañaba esta manifestación de autoridad. Así, el forzado monopolio de la violencia se demostraba en estos actos de prevención general que constituían una "razón de Estado". Esta relación estuvo simbolizada por el verdugo, extraña figura nacida conjuntamente con el proceso inquisitivo, quien con su infamia, que transmitía de generación en generación, recordaba la expropiación de la venganza particular por la autoridad estatal. ${ }^{5}$
\end{abstract}

As penas eram extremamente cruéis e executadas de forma lenta, aumentando ainda mais o sofrimento do condenado. O soberano queria que o condenado sentisse cada ato punitivo de forma dolorosa e cruel. Por esta razão, a pena tinha como objeto de punição o corpo do condenado, para nele deixar todas suas marcas. Neste período não havia penas pecuniárias, como por exemplo o pagamento de multas e cestas básicas. As penas eram apenas corporais, de modo que o corpo do condenado era o alvo principal da repressão penal.

Em sua obra "Vigiar e punir: nascimento da prisão", Michel Foucault descreve a punição aplicada a Damiens, em 2 de março de 1757, permitindo que o leitor possa imaginar com base em todos os detalhes descritos, como ocorriam os suplícios:

[Damiens fora condenado, a 2 de março de 1757], a pedir perdão publicamente diante da porta principal da Igreja de Paris [aonde devia ser] levado e acompanhado numa carroça, nu, de camisola, carregando uma tocha de cera acesa de duas libras; [em seguida], na dita carroça, na Praça de Greve, e sobre um patíbulo que aí será erguido, atenazado nos mamilos, braços, coxas e barrigas das pernas, sua mão direita

4 ZYSMAN QUIRÓS, Diego. Sociología del castigo: genealogia der la determinación de la pena. 1. ed. Buenos Aires: Didot, 2012. p. 53.

5 Ibid., p. 54. 
segurando a faca com que cometeu o dito parricídio, queimada com fogo de enxofre, e às partes em que será atenazado se aplicarão chumbo derretido, óleo fervente, piche em fogo, cera e enxofre derretidos conjuntamente, e a seguir seu corpo será puxado e desmembrado por quatro cavalos e seus membros e corpo consumidos ao fogo, reduzidos a cinzas, e suas cinzas lançadas ao vento. ${ }^{6}$

Durante este período, que antecedeu o Iluminismo, as penas eram extremamente cruéis. Havia a prática reiterada e injustificada de tortura e de castigos corporais e toda essa crueldade era sempre praticada em praça pública, como forma de se mostrar para toda a sociedade o que acontecia com aqueles que cometiam crimes: a gravidade dos suplícios em nome da vingança pública e da retribuição pelo delito cometido. A punição sempre ultrapassava a gravidade do delito cometido. Por meio destas punições, o Estado mostrava sua força e seu poder, intimidando a sociedade.

Nas lições de Diego Zysman Quirós, "mediante el castigo se buscaba, no sólo prevenir mediante la intimidación, sino aterrorizar con la desmesura, con una desproporcionalidad que realzaba la jerarquía del monarca y la de sus leyes, en una sociedad que se reconocía desigual" $"$.

O processo criminal tramitava sem a participação do acusado. Era privilégio absoluto da acusação saber sobre os fatos e aplicar a pena. O acusado não tinha direito a defesa e era interrogado uma única vez antes da prolação da sentença, que era sempre condenatória.

Dava-se valor absoluto à confissão do acusado. Mas na grande maioria dos casos a confissão era viciada e falsa. O acusado recebia diversos castigos corporais brutais antes de ser efetivamente processado e julgado, e aqueles que não resistissem à tortura, mesmo que fossem inocentes da prática criminal, acabavam confessando a autoria do crime, apenas para se verem livres do martírio. Acreditava-se que se o acusado conseguisse resistir à tortura deveria ser inocentado, pois sua resistência significava que ele era, de fato, inocente das acusações imputadas. Isso tudo perdurou até o fim do Século XVIII e início do Século XIX, quando pensadores e filósofos iluministas romperam com a ordem então vigente, buscando estabelecer uma nova ordem social, pautada em valores como a liberdade e a igualdade, afastando em absoluto as barbáries até então praticadas pelo soberano. Buscava-se com essa nova ordem social a dignidade da pessoa humana em todas suas acepções, inclusive na aplicação das sanções penais.

6 FOUCAULT, Michel. Vigiar e punir: nascimento da prisão. Rio de Janeiro: Vozes, 2014. p. 9.

7 ZYSMAN QUIRÓS, Diego. Sociología del castigo: genealogia der la determinación de la pena. 1. ed. Buenos Aires: Didot, 2012. p. 53. 
Assim, pouco a pouco foram desaparecendo os suplícios. As penas, que antes atingiam o corpo humano e causavam sofrimento ao condenado, passaram a ser executadas de forma menos física, priorizando mais o caráter corretivo da pena e não o seu caráter retributivo. Também houve uma notória alteração acerca da ideia do delito, que deixou de ser um pecado e uma agressão à Deus e passou a ser considerado uma agressão à sociedade. Recebeu destaque com relação à defesa desta nova corrente de pensamento que buscava o caráter humano da sanção penal o filósofo italiano Cesare Beccaria, também chamado de Marquês de Beccaria, que ficou conhecido na Europa após a edição de sua obra "Dei Delitti e delle Pene" (Dos Delitos e das Penas), publicada em 1764. Nesta obra, Cesare Beccaria teceu duras críticas ao sistema penal então vigente, atraindo o apoio de diversos pensadores e filósofos europeus, principalmente os filósofos franceses.

Cesare Beccaria se manifestou de forma clara contra os abusos então praticados pelo soberano, sobretudo com relação aos julgamentos secretos, tortura, penas infamantes, direito de vingança, pena de morte, entre outros.

O filósofo reprimiu e criticou o espetáculo da pena, até então praticado por meio dos suplícios, já que o soberano via nesses espetáculos em praça pública a efetividade da aplicação da sanção, sob o fundamento de que a população, vendo o que o Estado era capaz de fazer com um criminoso, optava por não violar uma norma de conduta. Cesare Beccaria acreditava que era a própria condenação aplicada ao infrator da norma que seria uma efetiva forma de prevenção da prática de novos crimes, pois deixaria um sinal negativo na pessoa do condenado, e não o espetáculo em si.

Assim se pronunciou Cesare Beccaria sobre as torturas:

[...] É uma barbárie consagrada pelo uso na maioria dos governos aplicar a tortura a um acusado enquanto se faz o processo, quer para arrancar dele a confissão do crime, quer para esclarecer as contradições em que caiu, quer para descobrir os cúmplices ou outros crimes de que não é acusado, mas dos quais poderia ser culpado, quer enfim porque sofistas incompreensíveis pretenderam que a tortura purgava a infâmia. [...] A tortura é, muitas vezes, um meio seguro de condenar o inocente fraco e de absolver o celerado robusto. É esse, de ordinário, o resultado terrível dessa barbárie que se julga capaz de produzir a verdade, desse uso digno dos canibais, e que os romanos, malgrado a dureza dos seus costumes, reservavam exclusivamente aos escravos, vítimas infelizes de um povo cuja feroz virtude tanto se tem gabado. ${ }^{8}$

Cesare Beccaria argumentava já naquela época, que sob tortura qualquer pessoa iria admitir a prática de um crime para que cessasse a tortura. Assim, ao contrário do que acreditavam os monarcas, a tortura não era um meio eficaz para se chegar à verdade.

8 BECCARIA, Cesare. Dos delitos e das penas. Tradução de Paulo M. Oliveira; prefácio de Evaristo de Moraes. São Paulo: Edipro, 2015. p. 40-42. 
A propósito, importante mencionar que durante o Antigo Regime as penas eram aplicadas de acordo com a condição social do condenado. Ao nobre era concedido o privilégio de ter a cabeça cortada, assim o seu sofrimento seria menor, enquanto que aos indivíduos de camadas sociais mais baixas eram aplicadas penas cruéis, desumanas e com mais sofrimento, por meio dos suplícios.

Neste sentido, dentre a mais importante conquista atribuída à Cesare Beccaria está a busca pela proporcionalidade na aplicação das penas, conquista esta que se faz presente até os dias de hoje nos ordenamentos jurídicos ao redor do mundo, já que a proporcionalidade das penas é um princípio penal a ser seguido na execução da pena. O princípio da proporcionalidade determina que "as penas devem ser harmônicas com a gravidade da infração penal cometida, não tendo cabimento o exagero, nem tampouco a extrema liberalidade na cominação das penas nos tipos penais incriminadores". 9

Assim, o princípio da proporcionalidade determina que deve ser aplicada ao condenado uma pena proporcional à infração cometida. Vê-se assim a aplicação efetiva da justiça, na medida em que se busca dar a cada um aquilo que lhe é devido. Neste caso, a justiça está em aplicar ao condenado a pena devida proporcionalmente em razão da infração penal cometida. Assim, não há como ser aplicada a um condenado por roubo que empregou violência física e arma de fogo em sua ação delituosa o mesmo quantum de pena aplicada a um indivíduo que foi condenado por dano, em razão de ter pichado um muro de uma casa particular.

O historiador argentino Abelardo Levaggi assim descreve a importância de Cesare Beccaria:

\footnotetext{
Beccaria (Cesare Bonesana, Marqúes de), sin duda el más importante de los autores ilustrados, volcó sus ideas en el célebre libro De los delitos y de las penas (1764) $[\ldots]$.

Partiendo de la ley natural, que expresa "los princípios que impulsan a los hombres a vivir en sociedad", y siguiendo, como lo dice, "la huella luminosa de ese gran hombre" que fue Montesquieu, señaló el origen de las penas en la necesidad de defender a la sociedad de quienes atentan contra ella. Pero la pena debe derivar de una absoluta necesidad y "sólo las leyes pueden decretar las penas correspondientes a los delitos, y esta autoridad no puede residir sino en el legislador que representa a toda la sociedad unida por un contracto social". Debe existir proporción entre los delitos y las penas, porque "si se establece una pena igual para dos delitos que ofenden de manera desigual a la sociedad, los hombres no hallarán un obstáculo más fuerte para cometer el delito mayor, si a éste encuentran unida mayor ventaja".
}

9 NUCCI, Guilherme de Souza. Manual de Direito Penal: parte geral - parte especial. 7. ed. São Paulo: Revista dos Tribunais, 2011. p. 89. 
El fin de las penas no es el de atormentar y afligir a un ser sensible, ni tampoco el de dejar sin efecto un delito ya cometido; el fin "no es otro que el de impedir al reo que ocasione nuevos daños a sus conciudadanos, y el de disuadir a los demás de hacer como hizo aquél. En consecuencia, las penas y el método de infligirlas debe ser escogido de modo que, al conservarse la proporción, produzca una impresión más eficaz y más duradera en el ánimo de los hombres y menos atormentadora em el cuero del reo".

Combatió la tortura y abogó por la benignidad de las penas, convencido de que "la certidumbre de un castigo, aunque moderado, produce siempre impresión más honda que el temor de otro más terrible unido a la esperanza de la impunidad". ${ }^{10}$

Em que pese não existir um consenso doutrinário acerca de quando e com quem teria surgido o estudo científico da Criminologia, não há dúvidas de que Cesare Beccaria exerceu importante papel no discurso criminológico enquanto estudo, principalmente pelas críticas que teceu ao sistema então vigente, qual seja, o Absolutismo. Foi Beccaria quem contribuiu de forma valorosa e notória para a criação da chamada "Escola Clássica", cujos maiores expoentes foram também Pablo Anselmo von Feuerbach, Francesco Carrara e Giovanni Carmignani.

A propósito, a Escola Clássica Criminal, estava pautada no livre arbítrio e em razão disso, a pena tinha apenas e tão somente um aspecto retributivo. Para Francesco Carrara a pena é um conteúdo necessário do direito. É o mal que a autoridade pública inflige a um culpado por causa de seu delito:

A pena não é simples necessidade de justiça que exija a expiação do mal moral, pois só Deus tem a medida e a potestade de exigir a expiação devida, tampouco é uma mera defesa que procura o interesse dos homens às expensas dos demais; nem é fruto de um sentimento dos homens, que procuram tranquilizar seus ânimos frente ao perigo de ofensas futuras. A pena não é senão a sanção do preceito ditado pela lei eterna, que sempre tende à conservação da humanidade e a proteção de seus direitos, que sempre procede com observância às normas de Justiça, e sempre responde ao sentimento da consciência universal. ${ }^{11}$

Para a Escola Clássica a pena é um mal imposto ao indivíduo que merece um castigo em vista de uma falta praticada considerada crime, que voluntária e conscientemente cometeu. A finalidade da pena era então o restabelecimento da ordem externa na sociedade.

O professor Sérgio Salomão Shecaira em sua obra "Criminologia" assim sintetiza a questão da aplicação da pena para os autores da Escola Clássica:

[...] Para a escola criminológica clássica, fundada no contratualismo de uma burguesia em ascensão, a pena era a reparação do dano causado pela violação de um contrato (o contrato social de Rousseau). No direito civil, quando uma parte

10 LEVAGGI, Abelardo. Historia del Derecho Penal Argentino. Buenos Aires: Perrot, 1978. p. 95-96.

11 LYRA, Roberto. Novíssimas escolas penais. Rio de Janeiro: Borsoi, 1956. p. 6. 
viola o contrato, surge a reparação como resultado inevitável daquele descumprimento. No direito penal de uma sociedade baseada metaforicamente nesse mesmo contrato, não há como evitar a necessária reparação do dano por meio da pena. Daí é que surgem penas certas e determinadas, como decorrência dessa matemática reparatória fixa. (nossos grifos) ${ }^{12}$

E mais:

Para os clássicos, a pena é uma retribuição jurídica que tem como objetivo o restabelecimento da ordem externa violada. A pena, como negação da negação do direito (segundo Hegel), ou o justiçamento do último assassino que se achasse na prisão, caso a sociedade fosse se dissolver (segundo Kant), são exemplos de como a pena tinha como objetivo o restabelecimento da ordem externa (leia-se jurídica) violada. $^{13}$

Para o historiador argentino Abelardo Levaggi:

Las proposiciones fundamentales de los clásicos, adheridos en su mayoría a la filosofia iusnaturalista (Bentham profesó el positivismo legal y combatió la doctrina del derecho natural) fueron las siguientes:

- el derecho penal tiene un fin tutelar, procura sustraer a los hombres de la tiranía de sus semejantes y ayudarlos a eludir la tiranía de sus propias pasiones;

- no existe delito sin una ley previa que lo determine;

- la ley debe individualizar a la pena del delito, que debe ser aplicada ciegamente por el juez (sistema de las penas fijas);

- la pena tiene por finalidad el restablecimiento del orden público alterado por el delito y tiene el carácter de mal equivalente al que el delincuente ha ocasionado;

- la pena debe ser proporcionada al delito, cierta, conocida, segura;

-oposición, en principio, a las penas capitales, aflictivas e infamantes;

- el delincuente es responsable cuando sabe lo que hace y quiere hacerlo

(libre albedrío); si faltan la inteligência o la voluntad libre, no existe responsabilidad;

- el libre albedrío con que actúa el delincuente hace que el delito deba ser considerado, en principio, objetivamente, adecuando el legislador a éste, y no a su autor, la pena;

—necesidad de rodear de garantías tanto al processo penal como a la aplicación de las penas. ${ }^{14}$

Em contrapartida às ideias da Escola Clássica, surgiu a Escola Positiva, cujos estudos mais emblemáticos nos remetem à figura de Cesare Lombroso, que foi seguido também por Enrico Ferri e Raffaele Garofalo. Para a Escola Positiva o crime é um fenômeno natural e social e a pena meio de defesa social. Para os seguidores desta escola, o objeto de estudo é o

12 SHECAIRA, Sérgio Salomão. Crimimologia. São Paulo: Revista dos Tribunais, 2004. p.93.

13 Ibid., p.94.

14 LEVAGGI, Abelardo. Historia del Derecho Penal Argentino. Buenos Aires: Perrot, 1978. pp.97. 
sujeito em si e não o ato por ele praticado. Em que pese a rica contribuição dada por Beccaria, acredita-se que a Criminologia surgiu como ciência graças aos estudos de Lombroso, daí porque ele é considerado o criador da Criminologia. Foi a partir de Lombroso que os cientistas passaram a criticar as ideias principiológicas dos filósofos iluministas, encontrando na Ciência e em seus estudos empíricos falhas nos princípios então vigentes da liberdade, da igualdade e do livre arbítrio para o cometimento de delitos a partir do momento em que defendiam que o criminoso assim o era por razões de determinismo social. O delito não era, então, uma questão social e jurídica, como sustentavam os clássicos, mas sim um fenômeno biológico. Para Lombroso o criminoso era um ser atávico que representava a regressão do homem ao seu estado primitivo. "É um selvagem que já nasce delinquente". ${ }^{15}$

Enrico Ferri, sucessor de Lombroso, criou a chamada sociologia criminal. Ao contrário de Lombroso que pautava sua análise nos aspectos biológicos do ser, Ferri baseou suas análises nas ciências sociais, afastando-se do reducionismo exclusivamente antropológico de Lombroso. Para Ferri, “[...] o fenômeno complexo da criminalidade decorria de fatores antropológicos, físicos e sociais". ${ }^{16}$ Para Ferri, "a razão e o fundamento da reação punitiva é a defesa social, que se promove mais eficazmente pela prevenção do que pela repressão as fatos criminosos". ${ }^{17}$

O professor Sérgio Salomão Shecaira em sua obra "Criminologia" assim sintetiza a questão da aplicação da pena para os autores do positivismo:

[...] o crime passa a ser reconhecido como um fenômeno natural e social, sujeito às influências do meio e de múltiplos fatores, exigindo o estudo da criminalidade a adoção do método experimental. A responsabilidade penal é responsabilidade social, por viver o criminoso em sociedade, tendo por base a periculosidade. A pena será, pois, uma medida de defesa social, visando à recuperação do criminoso. Tal medida, ao contrário do que pensavam os clássicos, defensores da pena por tempo determinado, terá denominação de medida de segurança e será por tempo indeterminado, até ser obtida a recuperação do condenado. O criminoso será sempre psicologicamente um anormal, temporária ou permanentemente. (nossos grifos) ${ }^{18}$

Feita essa breve contextualização acerca da evolução da aplicação da pena ao longo da história da humanidade, cabe agora falarmos sobre a pena propriamente dita.

A pena constitui a sanção imposta pelo Estado ao autor de um crime após um processo democrático, respeitando-se todas as garantias asseguradas ao acusado, sobretudo o

15 SHECAIRA, Sérgio Salomão. Crimimologia. São Paulo: Revista dos Tribunais, 2004. p. 96-97.

16 Ibid., p. 99.

17 Ibid., loc. cit.

18 Ibid., p. 103. 
contraditório e a ampla defesa. A pena representa a retribuição ao delito perpetrado e a prevenção a novos crimes. É a consequência mais importante que decorre da prática de uma infração penal.

Para fins didáticos, a doutrina subdivide a função preventiva da pena em dois aspectos, o geral e o especial, que por sua vez se subdividem em outros dois grupos. O Desembargador do Tribunal de Justiça do Estado de São Paulo Guilherme de Souza Nucci explica que:

[...] O caráter preventivo da pena desdobra-se em dois aspectos, geral e especial, que se subdividem em outros dois. Temos quatro enfoques: a) geral negativo, significando o poder intimidativo que ela representa a toda a sociedade, destinatária da norma penal; b) geral positivo, demonstrando e reafirmando a existência e eficiência do Direito Penal; c) especial negativo, significando a intimidação ao autor do delito para que não torne a agir do mesmo modo, recolhendo-o ao cárcere, quando necessário e evitando a prática de outras infrações penais; d) especial positivo, que consiste na proposta de ressocialização do condenado, para que volte ao convívio social, quando finalizada a pena ou quando, por benefícios, a liberdade seja antecipada. ${ }^{19}$ (grifos no original)

Em termos gerais, a função da pena é: i) a retribuição ao delito praticado; ii) a prevenção da sociedade, no sentido de evitar a prática de novos crimes; iii) a reeducação (ressocialização) do condenado, e por fim; iv) a reafirmação do Direito Penal, no sentido de mostrar para a sociedade que existem normas de conduta a serem seguidas e aqueles indivíduos que desrespeitarem tais normas serão punidos pelo Estado - esta não deixa de ser uma variante da função preventiva da pena, pois intimida a sociedade para que o crime seja evitado.

Vale transcrever também as lições do historiador argentino Abelardo Levaggi acerca do tema:

\begin{abstract}
De acuerdo con las Partidas, la pena es reparación de daño y castigo impuesto según la ley al delincuente por el delito cometido. El fin político perseguido por la ley penal fue - según Tomás y Valiente - represivo, no correccional, englobando dentro de la expresión repressivo a dos propósitos del legislador sólo separables conceptualmente: el de castigar (escarmentar o expiar) al culpable y el de dar ejemplo a los demás por médio del temor (intimidar). La Monarquía tenía ideia de que el único procedimiento eficaz para combatir la delincuencia era la represión, y no otros, acaso más encomiables moralmente, pero inútiles en la práctica.
\end{abstract}

Sin embargo, la doctrina de los autores, además de la expiación y la intimidación, incluyó entre los fines de la pena a la corrección del delincuente, entendida ésta, como es obvio, según el concepto de entonces.

$[\ldots]$

Al fin intimidatorio o ejemplarizador respondieron las Partidas al declarar que "los delitos deben ser escarmentados severamente, para que sus autores reciban la pena

19 NUCCI, Guilherme de Souza. Manual de Direito Penal: parte geral - parte especial. 7. ed. São Paulo: Revista dos Tribunais, 2011. p. 391. 
que merecen, y los que lo oyeren se espanten y tomen por ende escarmiento" $[\ldots]^{20}$ (nossos grifos)

Ainda sobre as funções da pena, vale transcrever trecho da aula ministrada por Michel Foucault em 3 de janeiro de 1973 no Collège de France, as quais foram compiladas e deram origem ao livro "A Sociedade Punitiva":

Quero justificar o título do curso e falar dessa noção de punição. Se tomei precisamente essa noção banal, ingênua, frágil, pueril, foi justamente por querer retomar as coisas no próprio nível de seu desenvolvimento histórico, começando pela análise daquilo que poderá ser chamado de "táticas finas da sanção". Começarei discernindo algumas delas. Parece-me possível discernir quatro grandes formas de táticas punitivas, que definirei como verbos em vez de substantivos.

1. Excluir. Esse termo é aqui empregado no sentido estrito, e não, como no texto de Lévi-Strauss, no sentido de encarcerar, mas no sentido de exilar, expulsar, pôr para fora. Com essa tática punitiva, trata-se de proibir a presença de um indivíduo nos lugares comunitários ou sagrados, de abolir ou proibir em relação a ele todas as regras de hospitalidade. Trata-se de privá-lo de sua casa, suprimir até a realidade de seu lar, como quando se queima a casa de um bandido ou também - segundo um direito medieval que se prolongou por muito tempo, até nas práticas revolucionárias - [quando se] incendeia o teto da casa da pessoa que se quer banir. Essa tática foi posta em prática de maneira privilegiada na penalidade da Grécia arcaica.

2. Organizar um ressarcimento, impor uma compensação. Nessa tática, a ruptura da regra e a infração vão provocar dois procedimentos: [por um lado,] a emergência de alguém, indivíduo ou grupo, que será constituído como vítima do dano e poderá, assim, exigir reparação; a culpa [por outro lado,] provocará algumas obrigações [para] aquele que é considerado infrator. Assim, em torno da infração, não haverá o fenômeno de vazio do primeiro caso, mas a constituição de toda uma rede específica de obrigações, comparável a uma dívida que seria preciso reembolsar ou a um dano que seria preciso reparar. Aquele que infringiu as regras fica assim forçosamente preso a um conjunto de compromissos que o coagem. [...]

3. Marcar. Fazer uma cicatriz, deixar um sinal no corpo, em suma, impor a esse corpo uma diminuição virtual ou visível, ou então, caso o corpo real do indivíduo não seja atingido, infligir uma mácula simbólica a seu nome, humilhar seu personagem, reduzir seu status. [...] O indivíduo que tiver cometido a infração ficará assim marcado por um elemento de memória e reconhecimento. Nesse sistema, a infração já não é aquilo que deve ser ressarcido, compensado, reequilibrado, portanto até certo ponto apagado; ao contrário, é aquilo que deve ser ressaltado, que deve escapar ao esquecimento.

$[\ldots]$

4. Encarcerar. Tática que praticamos, cuja instauração definitiva se situaria na virada do século VXIII para o XIX..$^{21}$ (nossos grifos)

20 LEVAGGI, Abelardo. Historia del Derecho Penal Argentino. Buenos Aires: Perrot, 1978. p. 53-54.

21 FOUCAULT, Michel. A sociedade punitiva: curso do Collège de France. São Paulo: WMF Martins Fontes, 2015. p. 7-9. 
A título de ilustração, demonstrando a aplicação de tais conceitos na prática, podemos citar o artigo 59 do Código Penal Brasileiro ${ }^{22}$, que estabelece que o juiz deve fixar a pena de modo a ser necessária e suficiente para a reprovação e prevenção do crime. Já o artigo 10 da Lei de Execução Penal dispõe que "a assistência ao preso e ao internado é dever do Estado, objetivando prevenir o crime e orientar o retorno à convivência em sociedade". Aqui vemos de forma expressa a função reeducativa e ressocializadora da pena adotadas pelo ordenamento jurídico penal brasileiro.

Importante também mencionar o disposto no artigo $5^{\circ}$, item 6 da Convenção Americana de Direitos Humanos de 1969 (Pacto San Jose da Costa Rica), que em seu art. 5, item 6 dispõe que "As penas privativas de liberdade devem ter por finalidade essencial a reforma e a readaptação social dos condenados."

Vemos, portanto, que a função da pena é, por excelência, punir o infrator da norma, aquele que trouxe desequilíbrio e desordem para a sociedade, mas, ao mesmo tempo, reeducálo e prepará-lo para o retorno à sociedade.

A pena é a mais importante das consequências jurídicas do delito. Consiste na privação ou restrição de bens jurídicos, com lastro na lei, imposta pelos órgãos jurisdicionais competentes ao agente de uma infração penal. ${ }^{23}$

A letra da lei é atraente e muito nobre é a intenção do legislador, mas bem sabemos que na prática, sobretudo nos países da América do Sul, isto é impossível de acontecer. Alguns países latinos contam com altos índices de criminalidade. Os presídios são superlotados e os encarcerados convivem, diariamente, com situações de extrema violação de direitos humanos, sobretudo da dignidade humana.

Por conta da ineficácia e da ineficiência do Estado no sentido de fazer cumprir a função da pena e ainda em razão dos elevados índices de criminalidade, tem surgido em alguns países da América Latina o que se chama de "justiça restaurativa", instituto por meio da qual o Estado atua "criando oportunidades para que as pessoas envolvidas no conflito (autor e receptor do fato, familiares e comunidade) possam conversar e entender a causa real

22 Art. 59 - O juiz, atendendo à culpabilidade, aos antecedentes, à conduta social, à personalidade do agente, aos motivos, às circunstâncias e conseqüências do crime, bem como ao comportamento da vítima, estabelecerá, conforme seja necessário e suficiente para reprovação e prevenção do crime:

I - as penas aplicáveis dentre as cominadas;

II - a quantidade de pena aplicável, dentro dos limites previstos;

III - o regime inicial de cumprimento da pena privativa de liberdade;

IV - a substituição da pena privativa da liberdade aplicada, por outra espécie de pena, se cabível. (grifamos)

23 Neste sentido: CUELLO CALÓN, Eugenio. La moderna penología. Barcelona: Bosch, 1974. p. 16. 
do conflito, a fim de restaurar a harmonia e o equilíbrio entre todos" ${ }^{24}$, transformando o processo em uma possibilidade de composição e conciliação entre autor, Estado e vítima.

$\mathrm{Na}$ visão moderna e atual do Direito Penal busca-se evitar ao máximo o encarceramento do indivíduo, aplicando-se formas alternativas de pena ao condenado. Especificamente no Brasil, exemplo claro dessa nova justiça restaurativa encontra-se expresso na Lei $n^{\circ}$ 9.099/95, a Lei dos Juizados Especiais Criminais, que permite a transação penal para determinados delitos, em substituição à aplicação de pena ao infrator da norma penal evitando assim o seu encarceramento. Há ainda os institutos da substituição da pena privativa de liberdade, previsto no artigo 44 e seguintes do Código Penal e ainda a suspensão condicional da pena, prevista no artigo 77 do mesmo diploma legal.

É verdade que o Brasil ocupa papel de destaque quando o assunto é população carcerária. Temos uma das maiores populações carcerárias do mundo e esses números tendem a aumentar cada vez mais, especialmente em razão do rigor que o legislador infraconstitucional vem dando ao Direito Penal, como se aumentar penas e criar tipos penais fossem as soluções corretas para enfrentar o problema da criminalidade. Se de um lado o que se busca é acabar com a questão da criminalidade, por outro, o que se tem é uma falha técnica legislativa ao eleger os instrumentos e ferramentas que serão utilizados nesta empreiada.

Não há como negar que o Direito Penal e o Direito Processual Penal vivem uma nova era. Uma nova realidade, onde novos interesses e novos direitos surgem. O cientista do Direito e o aplicador da lei devem estar preparados para esta nova realidade. A primeira lição que devem ter em mente é o desapego ao Direito Penal estritamente punitivo. Hoje busca-se evitar o encarceramento do indivíduo, aplicando-se medidas sancionadoras mais efetivas como forma de reeducação, ressocialização e prevenção a novos delitos. Cada caso deve ser analisado de forma individual, a fim de se verificar a efetividade da pena em cada situação concreta, pois nem sempre o encarceramento é a melhor solução. O cientista do Direito deve estar preparado para enfrentar esta nova realidade, desapegando-se de conceitos ultrapassados e ideias já antigas acerca da finalidade do Direito Penal e da função da pena.

Veremos a seguir, as principais teorias dos fins da pena.

24 JUSTIÇA RESTAURATIVA: HISTÓRICO - CENTRO DE APOIO OPERACIONAL DAS PROMOTORIAS DA CRIANÇA E DO ADOLESCENTE. Disponível em: http://www.crianca.mppr.mp.br/pagina-1711.html. Acesso em 27 mar. 2019. 


\section{TEORIAS DOS FINS DA PENA}

São inúmeras as teorias que buscam justificar os fins e os fundamentos da pena. Para fins didáticos a doutrina as divide em quatro grupos que veremos a seguir.

2.1 Teorias absolutas ou de justiça - pena retributiva e expiatória.

Foram defensores das teorias absolutas entre outros, Carrara, Petrocelli, Maggiore e Bettiol na Itália, Binding, Maurach, Welzel e Mezger na Alemanha. Para as teorias absolutas a pena é a retaliação e a expiação, uma exigência absoluta de justiça, com fins aflitivos e retributivos, opondo-se a qualquer finalidade utilitária.

Nas lições de Cezar Roberto Bitencourt:

[...] segundo o esquema retribucionista, é atribuída à pena, exclusivamente, a difícil incumbência de realizar a Justiça. A pena tem como fim fazer Justiça, nada mais. A culpa do autor deve ser compensada com a imposição de um mal, que é a pena, e o fundamento da sanção estatal está no questionável livre arbítrio, entendido como a capacidade de decisão do homem para distinguir entre o justo e o injusto ${ }^{25}$.

As chamadas teorias absolutas estão apoiadas na filosofia do idealismo, especialmente em Kant ${ }^{26}$ e Hegel. A pena encontra seu fundamento somente em sua referência ao delito e segundo sua gravidade determina-se a quantia de pena que será aplicada. Assim, a pena é a justa retribuição e compensação ao mal causado pela prática do crime. É dizer: a prática de um crime representa o desrespeito à vontade geral da sociedade representada pela soberania exercida pelo Estado por meio da ordem jurídica. Neste contexto, a pena teria a função de compensar e retribuir a conduta do agente que violou a ordem jurídica, confirmando assim a ordem jurídica vigente.

Para os seguidores desta teoria o condenado deve ser castigado apenas por ter delinquido. Não se fala sobre a utilidade da pena, de modo que esta teoria ignora toda e qualquer função preventiva - especial ou geral - da pena. "A aplicação da pena decorre da simples infringência da lei penal, isto é, da simples prática do delito"27.

Immanuel Kant dizia que:

25 BITENCOURT, Cezar Roberto. Manual de direito penal. São Paulo : Saraiva, 1999. p. 99.

26 A lei penal constitui um imperativo categórico, uma determinação de justiça, independentemente de toda consideração finalista.

27 BITENCOURT, Cezar Roberto. Falência da pena de prisão: causas e alternativas. São Paulo: RT, 1993. p. 103. 
A pena judicial (poena forensis), distinta da natural (poena naturalis), pela que o vício pune-se a si mesmo e que o legislador não leva absolutamente em conta, não pode nunca servir simplesmente para fomentar outro bem, seja para o próprio delinqüente, seja para a sociedade civil, mas deve ser-lhe imposta tão-somente porque delinqüiu; porque o homem nunca pode ser utilizado como meio senão para si mesmo, nem confundido com os objetos de direito real (Sachenrecht); diante disso, protege-se sua personalidade inata, ainda que possa ser condenado a perder a personalidade civil. Antes de se pensar em tirar dessa pena algum proveito para si mesmo ou para seus concidadãos deve ter sido julgado como merecedor de punição. A lei penal é um imperativo categórico $[\ldots]^{28}$. (nossos grifos)

Georg Wilhelm Friedrich Hegel também era defensor de uma teoria retributiva da pena. Sua tese resumia-se em sua conhecida frase: "A pena é a negação da negação do Direito". ${ }^{29} \mathrm{O}$ fundamento da pena em Hegel é jurídico, já que ela se destina a restabelecer a vigência da vontade geral, que é a lei, negada que fora pela vontade do delinqüente. Ela é uma exigência de Justiça e se funda na pura retribuição. É um fim em si mesma e não serve a qualquer outro propósito que não seja o de recompensar o mal com o mal (fundamento metafísico Kantiano). Não tem, pois, uma finalidade, se considerada objetivamente. ${ }^{30}$

A grande crítica que pode ser formulada contra esta teoria, em minha opinião, é a ideia de que a pena está fundada apenas no aspecto punitivo e retributivo de sua aplicação, é dizer, a pena representa apenas e tão somente a retribuição ao agente que infringiu a norma penal. É apenas um castigo aplicado ao agressor da norma violada, impondo-se a ele o dever de pagar pelo mal cometido. Assim, sob esta perspectiva, a pena não representa nenhuma utilidade à sociedade, apenas pressupõe a sua necessidade: retribuir o mal praticado pelo agente criminoso.

A privação da liberdade, o isolamento do indivíduo, a imposição de perda de contato daquele que infringiu a ordem jurídica com seus familiares, a privação de luz do sol, de espaço, de condições dignas de vida entre várias outras situações que decorrem da aplicação de uma pena não são aptas à ressocializar o indivíduo. Vê-se, portanto, a manifesta falta de utilidade da aplicação da pena sob a perspectiva desta corrente, especialmente pelo fato de o indivíduo ser visto como mero instrumento de aplicação da pena para esta teoria. Além disso, compensar um mal com outro mal não é lícito e muito menos democrático, especialmente porque a função do Direito Penal é tutelar e proteger bens jurídicos e não promover atos de vingança social.

28 KANT, Immanuel. La metafísica de las costumbres. Trad. Adela Cortina Orts e Jesús Conill Sancho. Madrid: Tecnos, 1999. p. 166-167.

29 Ibid., loc. cit.

30 SCHECAIRA, Sérgio Salomão; CORRÊA JUNIOR, Alceu. Pena e Constituição. São Paulo: RT, 1995. p. 99. 
Nos dias de hoje, a noção de retribuição jurídica significa que a pena deve ser proporcional ao injusto praticado. Logo, essa concepção não representa um sentimento de vingança social, mas equivale a um princípio limitativo, segundo o qual o delito praticado deve ser o fundamento e o limite da pena, que deve ser sempre proporcional à gravidade do injusto praticado.

2.2 Teorias relativas - prevenção geral - prevenção especial - concepção utilitária da pena

Os seguidores da teoria relativa encontram o fundamento de validade da pena na necessidade de evitar a prática futura de delitos. Trata-se de um instrumento preventivo de garantia social com o objetivo de evitar a prática de futuros delitos. Isso significa que a pena se fundamenta por seus fins preventivos gerais ou especiais e por razões de utilidade social.

A prevenção geral está relacionada com a intimidação, ou seja, com o temor causado nos indivíduos pela ameaça da aplicação da pena. Assim, busca-se a produção de efeitos inibitórios à realização de condutas delituosas, de modo que os indivíduos optem por não praticar crimes em razão do medo que terão de sofrer uma sanção penal.

Destacam-se entre os defensores da teoria da prevenção geral da pena, entre outros, Beccaria, Bentham, Feuerbach, Filangieri e Schopenhauer.

A propósito, Anselm Ritter von Feuerbach formulou a Teoria da Coação Psicológica, segundo a qual a pena previne a prática de delitos porque intimida ou coage psicologicamente seus destinatários: "é através do Direito Penal que se pode dar uma solução ao problema da criminalidade". 31

Por fim, importante mencionar que a prevenção geral está dividida em positiva ou negativa. A primeira, representa a ideia de que a pena possui função retributiva do injusto praticado, na exata medida da gravidade da conduta, reafirmando a existência do ordenamento jurídico, em especial do Direito Penal. Já a prevenção geral negativa significa o poder intimidativo exercido pela pena aplicada ao delinquente.

Interessantes as lições de Eugenio Raúl Zaffaroni, que afirma que: a prevenção geral positiva "[...] produciría un efecto positivo sobre los no criminalizados, pero no para disuadirlos mediante la intimidación, sino como valor simbólico reforzador de su confianza en el sistema social en general (y en el sistema penal en particular)" 32 enquanto que a prevenção

31 BITENCOURT, Cezar Roberto. Falência da pena de prisão: causas e alternativas. São Paulo: RT, 1993. p. 115.

32 ZAFFARONI, Eugenio Raúl. Manual de derecho penal: parte general. Buenos Aires: Ediar, 2017. p. 42. 
geral negativa "sostiene que la pena se dirige a quienes no delinquieron para que en el futuro no lo hagan"33.

A seu turno, a prevenção especial representa a atuação do Direito Penal e em especial da pena sobre a pessoa do delinquente, a fim de evitar que ele volte a cometer crimes no futuro. Assim, enquanto a prevenção geral, como o próprio nome diz, se destina à todos os membros em geral dentro de uma sociedade, a prevenção especial está direcionada exclusivamente ao indivíduo que praticou um ato ilícito. A pena é então, um mal necessário, na medida em que busca corrigir aquele que delinquiu. A prevenção especial também está dividida em positiva ou negativa. A primeira, representa a proposta trazida pela pena de ressocialização do delinquente, enquanto que a segunda representa intimidação daquele que praticou um delito, para que não volte a delinquir.

Nas lições de Eugenio Raúl Zaffaroni:

Las teorias más difundidas son las que desde 1830 se llaman relativas, o sea, las que asignan a la pena funciones prácticas y verificables. Existen dos grandes grupos de teorías legitimantes llamadas relativas: (a) las que sostienen que las penas actúan sobre los que no han delinquido son las llamadas teorías de la prevención general y se subdividen en negativas (disuasorias, provocan miedo) y positivas (reforzadoras, generan confianza); y (b) las que afirman que actúa sobre los que han delinquido, llamadas teorías de la prevención especial y que se subdividen en negativas (neutralizantes) y positivas (ideologias re: reproducen un valor positivo en la persona). ${ }^{34}$

Ao contrário das teorias absolutas, que viam na aplicação da pena apenas o caráter retributivo do mal praticado pelo agente que infringiu a ordem jurídica, as teorias relativas buscam criar uma finalidade para justificar a aplicação da pena. Assim, a pena deixa de ser um fim para ser um meio. Esta visão permite analisarmos a pena sob um aspecto utilitarista e instrumental.

Pelo que foi exposto, é possível verificar que para as teorias absolutas, uma vez praticado o delito, a pena surge como forma de retribuir ao agente o mal por ele praticado. Já para as teorias relativas, a aplicação da pena passa a ser um instrumento de função essencialmente preventiva à pratica de novos delitos pelos demais membros da sociedade, tendo em vista que a pena passa a ser vista como meio de defesa da sociedade por meio da intimidação.

Apesar de representar um importante avanço no tocante à finalidade da pena, que como dito, deixa de ser um fim para ser um meio, esta teoria também merece críticas. Isto

33 ZAFFARONI, Eugenio Raúl. Manual de derecho penal: parte general. Buenos Aires: Ediar, 2017. p. 39. 34 Ibid., p. 38. 
porque a pena é tratada como coação psicológica, ou seja, é uma ameaça imposta ao indivíduo no sentido de que se algum membro da sociedade não orientar sua conduta conforme as normas jurídicas daquela sociedade, um mal maior será contra ele aplicado, vale dizer, uma sanção penal. Esta aplicação servirá como prevenção aos demais membros, para que novos delitos não sejam igualmente praticados. Aqui reside a crítica: a pena representa uma coação psicológica, uma ameaça, um medo imposto aos indivíduos como forma de controle social. Cria-se assim um estado de terror no qual se presume que o indivíduo terá a capacidade racional de orientar as suas condutas, sem no entanto ser levado em conta o fato de que para esta teoria o indivíduo acaba sendo usado como meio para alcançar um propósito social coletivo. $\mathrm{O}$ indivíduo passa a ser um objeto da persecução estatal de finalidades preventivas. Não se pode perder de vista que a pena deve ser um instrumento de negação da vingança e deve ser utilizada como forma de limitação ao poder punitivo arbitrário do Estado.

\subsection{Teorias unitárias, ecléticas ou unificadas}

Os seguidores desta teoria buscam conciliar a função retributiva da pena com os fins de prevenção geral (positiva e negativa) e especial (positiva e negativa). Ou seja, buscam conciliar em uma única teoria, todos os fins da pena. O que se tem, então, é um compilado de todos os pressupostos de cada uma dessas teorias, sem deixar de lado o caráter retributivo da pena. Para Juarez Cirino dos Santos:

\footnotetext{
As teorias unificadas da pena criminal conjugaram as teorias isoladas com o objetivo de superar as deficiências particulares de cada teoria, mediante fusão das funções declaradas de retribuição, de prevenção geral e de prevenção especial da pena criminal. Então, a pena representaria (a) retribuição do injusto realizado, mediante compensação ou expiação da culpabilidade, (b) prevenção especial positiva mediante correção do autor pela ação pedagógica da execução penal, além de prevenção especial negativa como segurança social pela neutralização do autor e, finalmente, (c) prevenção geral negativa através da intimidação de criminosos potenciais pela ameaça penal e prevenção geral positiva como manutenção/reforço da confiança na ordem jurídica, etc. ${ }^{35}$
}

A pena encontra o seu fundamento de validade no ilícito praticado pelo delinquente e na necessidade de se evitar que outros indivíduos, ou mesmo que o próprio delinquente pratique novos delitos.

35 CIRINO DOS SANTOS, Juarez. Direito penal: parte geral. Santa Catarina: Empório do Direito, 2017. p. 430. 
Para os seguidores desta teoria a pena deve ser justa e proporcional à gravidade do delito praticado e à culpabilidade do autor e ainda, deve ser necessária e efetiva para a manutenção da ordem social.

Com base nos fundamentos dessa teoria é possível concluir que há uma conexão entre a natureza retributiva da pena e sua função de prevenção geral, na medida que ao retribuir o mal injusto praticado o ordenamento jurídico também está prevenindo para que o ilícito não volte a ser praticado. Assim, uma vez mais, a aplicação da pena acaba por, em última análise, reafirmar o ordenamento jurídico, em especial o Direito Penal.

Os adeptos dessa teoria defendem a proporcionalidade das penas, que devem ser aplicadas sempre com base na gravidade do delito praticado. Ou seja: cada caso deve ser considerado de forma isolada, para que se tenham penas justas e isonômicas. A pena deve ser sempre adequada e justa e ainda, proporcional ao injusto praticado e à culpabilidade do delinquente.

Para a teoria unitária ou eclética, a pena tem fundamento de validade no delito praticado e na prevenção da prática de novos delitos. Vemos, uma vez mais, que o delito praticado atua como fundamento e limite da pena que será aplicada ao caso concreto, com base nos postulados de proporcionalidade e igualdade. Mas aqui se faz uma crítica: reunir as funções da pena é suficiente para garantir a eficácia da aplicação da pena e ainda para superar as fraquezas e os defeitos de cada uma das teorias? Além disso, as teorias aqui conciliadas são contraditórias, sendo que cada qual tem uma finalidade que não se alinha à finalidade da outra. É dizer: teorias com finalidades e objetivos antagônicos são conjugadas. Essa fusão não será suficiente para superar as deficiências e fraquezas de cada uma das teorias isoladamente consideradas, o que tornaria sua aplicação ineficaz para os fins aos quais se propõe.

\subsection{Teorias negativas ou agnósticas}

A teoria negativa, também chamada de teoria agnóstica, coloca em evidência a descrença e a falta de confiança na existência de finalidades da pena e do poder punitivo do Estado. Para esta teoria as finalidades da pena declaradas expressamente pelo discurso oficial do Estado como a ressocialização do condenado e a prevenção da prática de novos crimes não podem ser alcançadas de forma efetiva em nosso sistema jurídico. Para esta teoria, as únicas finalidades da pena são a neutralização e a segregação do condenado. Daí porque recebe o nome de teoria negativa: porque nega e rejeita as funções da pena declaradas de forma 
expressa no discurso do Estado, quais sejam, as funções de retribuição e prevenção do crime. Enquanto as teorias positivas da pena encontram suas bases no discurso jurídico e oficial do Estado, no sentido de ser a pena uma decorrência jurídica do crime, a teoria negativa entende que o fundamento para aplicação da pena está no exercício da função política do Estado.

Acerca deste tema, Tobias Barreto afirmou:

\begin{abstract}
O conceito de pena não é um conceito jurídico, mas um conceito político. Este ponto é capital. $O$ defeito das teorias correntes em tal matéria consiste justamente no erro de considerar a pena como uma conseqüencia do direito, logicamente fundada [...]. Que a pena, considerada em si mesma, nada tem que ver com a idéia do direito, prova-o de sobra o fato de que ela tem sido muitas vezes aplicada e executada em nome da religião, isto é, em nome do que há de mais alheio à vida jurídica. (nossos grifos) $)^{36}$
\end{abstract}

Assim, a pena seria, para os adeptos desta corrente, decorrência do poder político do Estado. Tobias Barreto já dizia que: “quem procura o fundamento jurídico da pena deve também procurar, se é que já não encontrou, o fundamento jurídico da guerra." 37 A propósito deste pensamento, Eugenio Raul Zaffaroni faz menção ao jurista brasileiro Tobias Barreto ao dizer que:

\begin{abstract}
La idea de que la pena es extrajuridica y tiene semejanza con la guerra nos es nueva. Em América fue sostenida en el siglo XIX por uno de los penalistas más creativos e intuitivos de ese tiempo: el jurista del nordeste brasileño, cabeza visible de la llamada escuela de Recife, Tobias Barreto (1839-1889). Con gran lucidez afirmaba que el concepto de pena no es um concepto jurídico sino un concepto político y agregaba: quien busque el fundamento jurídico de la pena debe buscar también , si es que ya no lo halló, el fundamento jurídico de la guerra. ${ }^{38}$
\end{abstract}

Nilo Batista também entende a existência de uma função política não só da pena, mas também e sobretudo do Direito Penal. ${ }^{39}$

Eugenio Raul Zaffaroni tece diversas críticas ao conceito positivo da função da pena, verificada sob uma ótica da ciência social. O doutrinador argentino diz que nenhuma função da pena prevista pelas teorias positivas da pena é verificada na realidade social ${ }^{40}$. Para o autor, ninguém sabe quais são as funções da pena e que há uma multiplicidade de funções reais que não são eticamente positivas. Neste sentido, ensina Zaffaroni:

\footnotetext{
36 BARRETO, Tobias. Fundamentos do Direito de Punir. Revista dos Tribunais, São Paulo, n. 727, 1996. p.649/650.

37 Ibid., p.650.

38 ZAFFARONI, Eugenio Raúl. Manual de derecho penal: parte general. Buenos Aires: Ediar, 2017. p. 58-59.

39 Neste sentido: BATISTA, Nilo. Introdução crítica ao direito penal brasileiro. Rio de Janeiro: Revan, 2007. p. 21.

40 Neste sentido: ZAFFARONI, op. cit., p. 54.
} 
[...] la conclusión es que no se sabe cuál es la función del poder punitivo. [...] la multiplicidad de funciones hace imposible su definición positiva $\mathrm{y}$, además, como buena parte de sus funciones reales (enganar a la población, función latente) no son éticamente positivas (y otras veces son ellas mismas criminales), en caso de alcanzarse esa definición positiva no sería apta para ser incoporada al discurso jurídico - penal (no podría el estado asumir como propria uma definición según la cual el poder punitivo se caracterizara por su utilidad para eliminar disidentes, neutralizar excluidos y proveer recaudación ilícita).

Todo esto nos indica que el concepto de pena útil al derecho penal no se puede obtener de modo positivo (es decir, a partir de sus funciones reales, que em buena medida son desconocidas y las conocidas son altamente complejas y mutables y a veces delictivas), sino que la incoporación de estos datos al campo jurídico-penal nos impone la necesidad de construir um concepto negativo de pena, obtenido por exclusión y, al mismo tempo, confesando la imposibilidad de agotar el conocimiento de sus funciones, de modo que tendremos un concepto negativo y también agnóstico. ${ }^{41}$

Para Zaffaroni, o conceito negativo de pena pode ser construído considerando a pena como uma: (a) coerção, (b) que impõe uma privação de direitos ou uma dor, (c) que não repara e não restitui, e (c) que tampouco detém as lesões em curso ou neutraliza perigos iminentes. ${ }^{42} \mathrm{O}$ doutrinador argentino defende que a aplicação da pena é um exercício de poder que não tem função reparadora ou retributiva e tampouco representa coação administrativa direta. Se trata de uma coerção que impõe privação de direitos ou dor, que não responde aos outros modelos de solução ou prevenção de conflitos. Para Zaffaroni este conceito de pena é negativo tanto porque não traz nenhuma função positiva para a aplicação da pena quanto porque pode ser obtido por exclusão. É também agnóstico quanto à sua função porque parte do seu desconhecimento. ${ }^{43}$

A teoria negativa ou agnóstica da pena tem como fundamento modelos de estado de polícia e estado de direito. O estado de polícia caracteriza-se pelo exercício de poder vertical e autoritário e pela distribuição de justiça substancialista de grupos ou classes sociais, expressiva de direitos meta-humanos paternalistas, que suprime os conflitos humanos mediante as funções manifestas positivas de retribuição e prevenção da pena. $\mathrm{O}$ estado de direito caracteriza-se pelo exercício de poder horizontal e democrático e pela distribuição de justiça procedimental da maioria, expressiva de direitos humanos, que soluciona os conflitos por meio de regras democráticas estabelecidas com redução ou limitação do poder punitivo do estado de polícia. $^{44}$

41 ZAFFARONI, Eugenio Raúl. Manual de derecho penal: parte general. Buenos Aires: Ediar, 2017. p. 55.

42 Ibid., p. 56.

43 Ibid., loc. cit.

44 CIRINO DOS SANTOS, Juarez. Direito penal: parte geral. Santa Catarina: Empório do Direito, 2017. p. $433-$ 434. 
Assim, a teoria negativa, como o próprio nome já revela, nega as funções declaradas pelo discurso positivista do Estado, expressas no discurso de retribuição e de prevenção geral e especial. Para Juarez Cirino dos Santos:

Do ponto de vista científico, a teoria negativa/agnóstica da pena criminal é, antes e acima de tudo, uma teoria negativa das funções declaradas ou manifestas da pena criminal, expressas no discurso oficial de retribuição e de prevenção geral e especial (positivas e negativas), rejeitadas como falsas pelos autores - que recuperaram conceito de TOBIAS BARRETO para definir pena criminal como ato de poder político correspondente ao fundamento jurídico da guerra; em segundo lugar, é uma teoria agnóstica das funções reais ou latentes da pena criminal porque renuncia à cognição dos objetivos ocultos da pena criminal que seriam múltiplos e heterogêneos. (nossos grifos) $^{45}$

A teoria negativa da pena além de rejeitar o discurso jurídico-positivo que fundamenta a aplicação da pena busca conter a aplicação do poder polícia (leia-se: poder punitivo) por meio da ampliação dos poderes do estado de direito. Assim, estaria fundamentada a pena como fonte política de poder, permitindo a criação de políticas criminais com vistas ao exercício do humanismo penal democrático.

Assim, a teoria negativa seria uma "teoria crítica, humanista e democrática do Direito Penal, credenciada para influenciar projetos de política criminal e a prática jurídico-penal na América Latina". ${ }^{46}$

Referida teoria busca, ao que parece, uma reconstrução do Direito Penal sem, contudo, negar a existência do direito de punir. A meu ver, no entanto, não se trata de uma reconstrução do Direito Penal, mas sim, de uma nova leitura e interpretação que são feitas dos poderes de polícia e do estado de direito como forma de limitar o poder punitivo estatal, impedindo que abusos e arbitrariedades sejam cometidos, partindo do pressuposto de que aplicar uma pena é justamente limitar o poder estatal, impedindo abusos de autoridade, penas desumanas, degradantes e aflições e sofrimentos injustos que possam ser causados ao condenado. Aquele que cometeu um ilícito deverá por tal conduta responder, desde que a pena seja aplicada de forma humana e democrática.

Sob esse ponto de vista, a teoria tem por objetivo que a pena desempenhe o papel de garante do direito do condenado de não ser punido por outra entidade que não seja o Estado Democrático de Direito e ainda, de que as penas não serão arbitrárias e desmedidas, baseadas

45 CIRINO DOS SANTOS, Juarez. Direito penal: parte geral. Santa Catarina: Empório do Direito, 2017. p. 434. 46 Ibid., p. 435. 
no rigor e no excesso punitivo. Dizer que a pena tem função política é dizer que a pena não terá finalidade vingativa, limitando o poder punitivo estatal. Feita esta leitura e entendidos os pressupostos desta teoria, entendo bem contextualizadas as bases da teoria negativa, especialmente por impor uma nova leitura do direito de punir por meio da rejeição dos discursos oficiais da pena (funções retributivas e preventivas), qualificando a pena como ato do poder político no sentido de restringir a violência implícita do poder polícia e ampliando os poderes do estado de direito e por fim, garantindo que o indivíduo será punido apenas pela Estado.

\section{CONCLUSÃO}

Este artigo abordou como objeto de estudo a análise dos fundamentos da pena. A análise foi iniciada por meio de uma abordagem histórica acerca da evolução da aplicação da pena ao longo da história da humanidade, passando pelos povos primitivos, pela Antiguidade e pela Idade Média.

A seguir, foi realizada uma breve análise sobre as Escolas Clássica e Positiva, que buscaram desde o seu surgimento, fundamentar a aplicação da pena, cada qual com base em determinadas características que foram demonstradas ao longo da análise realizada por este trabalho. Dando continuidade ao estudo proposto, foram analisadas as teorias dos fins da pena.

A socialização ou ressocialização do indivíduo constitui uma forma de se atingir o equilíbrio e a ordem social, seja para a concretização do processo de reinserção social, seja para o exercício do controle social. Assim, a ressocialização do condenado é um dos principais objetivos da pena a ele aplicada. Espera-se que ao sair do sistema prisional o condenado possa retornar ao convívio social sem que represente um risco ou uma ameaça à sociedade ou a ele próprio.

Defendo a ressocialização do condenado como finalidade específica não apenas da execução da pena privativa de liberdade, mas de toda espécie de pena. A sanção penal, como dito no início do presente estudo, busca: i) a retribuição ao delito praticado; ii) a prevenção da sociedade no sentido de evitar a prática de novos crimes; iii) a reeducação (ressocialização) do condenado, e por fim; iv) a reafirmação do Direito Penal. Estas são as razões de ser da pena. Do contrário inexistiria justificativa para sua aplicação. 
Devemos apenas atentar para as propostas ressocializadoras no âmbito das penas privativas de liberdade, que a meu ver, estão totalmente dissociadas da realidade e não existem de forma efetiva.

Isto tudo porque não são todos os estabelecimentos prisionais que contam com instrumentos e mecanismos aptos a ressocializar gradativamente o preso. Oficinas de leitura, oficinas profissionalizantes, pequenos cursos técnicos são alguns dos exemplos dentre uma infinidade de mecanismos que poderiam ser adotados pelo sistema penal na tentativa de ressocializar o indivíduo preso. Além de trazer ocupação para a mente e corpo durante o período em que estão recolhidos e segregados do convívio em sociedade, tais instrumentos podem ainda preparar o indivíduo até mesmo para encontrar uma (re)colocação profissional para que possa retomar sua vida após o cumprimento da reprimenda.

O Estado está muito atrasado nesse aspecto e deve fazer esforços nesse sentido, tornando real a possibilidade de ressocialização do encarcerado.

A sociedade e a comunidade jurídica reclamam resultados ainda não alcançados pelo Direito Penal. Na prática, salta aos olhos do Direito Penal uma enorme antinomia entre o desejo do legislador e a realidade evidenciada. Os fundamentos filosóficos determinantes da prática legislativa não alcançam a finalidade pretendida e não se concretizam na aplicação e execução das penas.

O Estado revela-se absolutamente incompetente diante da questão penitenciária, razão pela qual a é necessário um esforço conjunto não apenas da comunidade jurídica em geral, mas também do Estado enquanto guardião da sociedade.

A grande verdade é que por mais que se busquem teorias legitimadoras da pena e por mais que se diga que há uma finalidade em aplicar uma sanção penal ao indivíduo que praticou uma infração penal, em pleno Século XXI ainda vemos na pena uma função essencialmente retributiva e vingativa. Por mais que se diga que a pena busca prevenir a prática de novas infrações penais e punir o agente transgressor da norma jurídica, o que temos é a existência de uma sentimento de raiva e vingança da sociedade: um conflito frontal entre a vingança e a sede de punir e castigar a qualquer custo, ainda que o apenado não seja de fato o verdadeiro transgressor da norma. A sociedade quer que alguém responda pelo ilícito praticado, ainda que não se encontre o verdadeiro culpado, alguém precisa responder por essa transgressão da lei e da ordem. O prazer de punir e o sentimento de vingança fundamentam a aplicação da pena, por mais que essa constatação não seja facilmente defendida e difundida. 
Quer isso dizer que a pena não é apenas uma mera consequência jurídica do crime, mas tem também uma finalidade: alimentar o desejo de vingança da população, desejo este que está presente em nossa sociedade desde os primórdios das civilizações humanas. É claro que esta finalidade não é legítima e muito menos jurídica, pois o Direito Penal existe para proteger bens jurídicos e não para promover vinganças.

Com a evolução da sociedade e com o fim dos suplícios passou a ser defendida a tese de que a sociedade encontrou uma forma justa e humana de punir aquele que infringiu uma norma penal. Assim, as penas passaram a ser proporcionais e justas ao mal cometido pelo transgressor da ordem jurídica.

Mesmo com a existência de teorias recentes e avançadas sobre a aplicação da pena e sobre as finalidades da pena, todas baseadas em estudos progressistas no campo do Direito Penal, sabemos que até os dias de hoje a pena traz consigo as noções de castigo e de vingança que muitos pensam terem ficado no passado. A ideia primitiva de vingança segue viva em nossa sociedade, mesmo diante de teorias humanitárias e progressistas que estudam os fundamentos da pena, baseadas em direitos e garantias fundamentais.

Não podemos fechar os olhos e ignorar este fato. A ciência jurídica busca teorias que fundamentem e justifiquem a aplicação a pena com base em princípios progressistas, racionais e humanitários e claro, com base sempre na dignidade humana do condenado. A sociedade, no entanto, segue caminho oposto, e busca na aplicação da pena excesso de castigo, excesso de dor e vingança. É o fundo emocional da pena.

Esse sentimento de vingança da população decorre da ineficiência e ineficácia do Estado em combater a criminalidade, o que acaba gerando sentimento de insegurança por parte dos indivíduos. Assim, quando um crime é cometido, o indivíduo quer a todo custo vingança: trata-se de uma reação punitiva.

O grande desafio do Estado é, além de encontrar as ferramentas e os mecanismos eficazes no combate à criminalidade, encontrar formas de neutralizar o sentimento de vingança e de castigo que permanece vivo dentro das sociedades modernas, reafirmando assim as ideias progressistas e humanitárias do Direito Penal moderno. 


\section{REFERÊNCIAS}

BARRETO, Tobias. Fundamentos do Direito de Punir. Revista dos Tribunais, São Paulo, n. $727,1996$.

BATISTA, Nilo. Introdução crítica ao direito penal brasileiro. Rio de Janeiro: Revan, 2007.

BECCARIA, Cesare. Dos delitos e das penas. Tradução de Paulo M. Oliveira; prefácio de Evaristo de Moraes. São Paulo: Edipro, 2015.

BITENCOURT, Cezar Roberto. Manual de direito penal. São Paulo : Saraiva, 1999.

BITENCOURT, Cezar Roberto. Falência da pena de prisão: causas e alternativas. São Paulo: RT, 1993.

CIRINO DOS SANTOS, Juarez. Direito penal: parte geral. Santa Catarina: Empório do Direito, 2017.

CUELLO CALÓN, Eugenio. La moderna penología. Barcelona: Bosch, 1974.

DOTTI, René Ariel. Bases e alternativas para o sistema de penas. 2. ed. São Paulo: Revista dos Tribunais, 1998.

FOUCAULT, Michel. Vigiar e punir: nascimento da prisão. Rio de Janeiro: Vozes, 2014.

FOUCAULT, Michel. A sociedade punitiva: curso do Collège de France. São Paulo: WMF Martins Fontes, 2015.

HOBBES, Thomas. Leviatã ou matéria, forma e poder de uma República eclesiástica e civil. São Paulo: Martins Fontes, 2003.

JUSTIÇA RESTAURATIVA: HISTÓRICO - CENTRO DE APOIO OPERACIONAL DAS PROMOTORIAS DA CRIANÇA E DO ADOLESCENTE. Disponível em:

http://www.crianca.mppr.mp.br/pagina-1711.html. Acesso em 27 mar. 2019.

KANT, Immanuel. La metafisica de las costumbres. Trad. Adela Cortina Orts e Jesús Conill Sancho. Madrid: Tecnos, 1999.

LEVAGGI, Abelardo. Historia del Derecho Penal Argentino. Buenos Aires: Perrot, 1978.

LYRA, Roberto. Novíssimas escolas penais. Rio de Janeiro: Borsoi, 1956.

MAQUIAVEL, Nicolau. O príncipe. 3. ed. São Paulo: Martins Fontes, 2004.

NUCCI, Guilherme de Souza. Manual de Direito Penal: parte geral - parte especial. 7. ed. São Paulo: Revista dos Tribunais, 2011.

SHECAIRA, Sérgio Salomão. Crimimologia. São Paulo: Revista dos Tribunais, 2004.

SCHECAIRA, Sérgio Salomão; CORRÊA JUNIOR, Alceu. Pena e Constituição. São Paulo: RT, 1995. 
ZAFFARONI, Eugenio Raúl. Manual de derecho penal: parte general. Buenos Aires: Ediar, 2017.

ZYSMAN QUIRÓS, Diego. Sociología del castigo: genealogia der la determinación de la pena. 1. ed. Buenos Aires: Didot, 2012.

\section{DADOS DA PUBLICAÇÃO}

Categoria: artigo submetido ao double-blind review.

Recebido em: 26/07/2019.

Aceito em: 07/03/2020. 
